\title{
Ford leaves a healthy legacy
}

GERALD FORD will no doubt be recorded in the history book as a President who, in his brief term of office, performed an extraordinary act of national healing, pouring a good deal of soothing balm on the political wounds inflicted by his predecessor. He did nothing too flamboyant, pursued few major new initiatives, and left the overall structure and operations of the federal government virtually intact. That pretty well sums up his record in science policy as well.

When he entered the White House two-and-a-half years ago, relations between the federal government and that slice of the population known as the scientific community were at an all-time low. When he handed over the reins to President Carter last week, the management and funding of federal science had been placed on a firmer footing, and the scientific community was, if not satisfied, at least mollified.

Mr Ford's most conspicuous act of healing in science affairs was the reinstatement of a science policy office in the White House, a move which has won much praise even though the new office came into being a scant five months before $\mathrm{Mr}$ Ford left Washington. Few of $\mathrm{Mr}$ Nixon's acts caused as much bitterness among scientists as his decision in 1973 to abolish the Office of Science and Technology and the President's Science Advisory Committee, bodies which had been providing scientific advice to the White House for more than a decade. $\mathrm{Mr}$ Ford's decision to reinstate a science advisory apparatus in the White House, though it took most of his Presidency to accomplish. has laid the basis for more rational scientific planning.

As far as budgets for research and development are concerned, $\mathrm{Mr}$ Ford has again placed matters on a relatively sound basis. When he came to power, he inherited a dismal state of affairs. During the previous few years, total federal support for research and development had declined as inflation more than gobbled up the small dollar increases proposed by $\mathrm{Mr}$ Nixon. Basic research was especially hard hit, with federal support declining in real terms by more than 20\% between 1969 and 1973 . And superimposed on the slow downward drift was a debilitating series of abrupt oscillations in funds for some programmes as $\mathrm{Mr}$ Nixon attempted to put a hold on public expenditure and to shift funds into priority areas at the expense of less politically favoured programmes. During Mr Ford's brief Presidency, there has been some real growth in funds, and basic research has been given a welcome boost.

The growth was particularly surprising because the three budgets which Mr Ford submitted to Congress all reflected his overriding concern to curb the overall rate of growth in the federal budget; science was given a financial boost while other programmes, particularly those in health and welfare, were held back. And $\mathrm{Mr}$ Ford's last budget, delivered to Congress just three days before his departure, continued the trend and even added some long overdue support for new research programmes in agriculture and the earth sciences.

But that does not mean $\mathrm{Mr}$ Ford has solved all the problems in federal support of research and development, and that he is handing President Carter a trouble-free scientific enterprise. Far from it.

Energy policy is in a mess, and oil imports are actually higher now than they were before the 1973 embargo. The overall strategy which has marked both the Nixon and Ford energy policies was to throw massive amounts of money into energy research and development, particularly nuclear technologies, in the hope of increasing energy supplies, Little attention has been paid to curbing demand, either through regulation or research on energysaving technologies, and President Carter has rightly criticised the outgoing Administration for its failure to establish a coherent energy policy. A particular failure has been the Ford Administration's attempts to curb nuclear proliferation, where policies have been thrown together in response to crises rather than developed by careful planning.

In the area of biomedical research. Mr Ford inherited a particularly dismal situation, and though he has made some progress, he is leaving his successor a number of problems. Two chief factors have led to disarray in biomedical research planning. The first was the passage of the National Cancer Act, which has caused funding for cancer to balloon while support for many other areas of research has languished. Although $\mathrm{Mr}$ Ford has tried to redress the balance in his budgets, he did not acknowledge, let alone implement, some modest recommendations for reform published last year by a Presidential commission.

The second principal area of irritation has been a continuing struggle between Republican Administrations and the Democratic Congress over the size of the budget for the Department of Health, Education and Welfare. Presidential vetoes and refusals to compromise on both sides have greatly delayed the passage of appropriations bills and caused federal funds to flow into the National Institutes of Health in a series of surges and trickles. Mr Ford's budgets, including his final proposals, have perpetuated the trend.

Nevertheless, on balance, $\mathrm{Mr}$ Ford is leaving his successor a surprisingly healthy scientific legacy, and few major changes in the federal science policy should be anticipated from the new Administration, at least in the next year or so. 